\title{
ELECTROCHEMICAL BEHAVIOR OF BIOCOMPATIBLE ALLOYS
}

\section{ELEKTROKEMIJSKO VEDENJE BIOKOMPATIBILNIH ZLITIN}

\author{
Ivana Petrášová, Monika Losertová \\ VŠB-Technical University of Ostrava, Faculty of Metallurgy and Materials Engineering, Department of Non-Ferrous Metals, Rafining and \\ Recycling, 17. listopadu 15/2172, 70833 Ostrava, Czech Republic \\ ivana.petrasova@vsb.cz \\ Prejem rokopisa - received: 2013-10-02; sprejem za objavo - accepted for publication: 2014-05-09
}

doi:10.17222/mit.2013.218

\begin{abstract}
The electrochemical behavior of Ti6Al4V and Ti22Nb alloys was studied in a $0.15 \mathrm{M}(0.9 \%)$ physiological sodium chloride solution at room temperature $(22 \pm 1){ }^{\circ} \mathrm{C}$. The experimental samples of the Ti6Al4V alloy were in different states of the thermomechanical treatment: as-received and hot rolled. The samples of Ti22Nb were studied in the as-cast, heat-treated and aged stages. The microstructural features of the Ti6Al4V alloy in three different states influenced not only the passivation but also the rate of corrosion that was $(0.12,0.07$ and 0.10$) \mathrm{mm}$ per year for the equiaxed $(\alpha+\beta)$, acicular $\alpha$ in the transformed $\beta$ grains and coarse lamellar $(\alpha+\beta)$ phases, respectively. The as-cast TiNb sample with a dendritic microstructure and very fine martensite showed the lowest corrosion rate of $0.26 \mathrm{~mm}$ per year unlike the specimens after the heat treatment and aging with the rate of $0.34 \mathrm{~mm}$ and $0.33 \mathrm{~mm}$ per year, respectively.
\end{abstract}

Keywords: Ti6A14V, Ti22Nb, electrochemical behavior

Preučevano je bilo elektrokemijsko vedenje zlitin Ti6Al4V in Ti22Nb v fiziološki raztopini natrijevega klorida $0,15 \mathrm{M}(0,9 \%)$ pri sobni temperaturi $(22 \pm 1){ }^{\circ} \mathrm{C}$. Vzorci zlitine Ti6Al4V za preizkuse so bili v različnih termomehanskih stanjih: $\mathrm{v}$ dobavljenem stanju in vroče valjani. Vzorci Ti22Nb so bili v litem stanju, toplotno obdelani in starani. Razlike v mikrostrukturi zlitine Ti6Al4V v treh različnih stanjih vplivajo na pasivacijo in na hitrost korozije, ki je bila $(0,12,0,07$ in 0,10$) \mathrm{mm}$ na leto pri enakoosnih $(\alpha+\beta)$, igličastih $\alpha$ - in transformiranih $\beta$-zrnih ter grobo lamelarnih fazah $(\alpha+\beta)$. Vzorci TiNb z dendritno mikrostrukturo in drobnim martenzitom so pokazali najmanjšo hitrost korozije $0,26 \mathrm{~mm}$ na leto, v primerjavi z vzorci po toplotni obdelavi in staranju pa z $0,34 \mathrm{~mm}$ in $0,33 \mathrm{~mm}$ na leto.

Ključne besede: Ti6A14V, Ti22Nb, elektrokemijsko vedenje

\section{INTRODUCTION}

The 316L stainless steel, cobalt-chromium alloys and Ti-alloys are three important classes of the most used metallic biomaterials, especially for orthopedic implants, even in highly loaded areas such as artificial joints ${ }^{1,2}$. Nowadays, titanium and its alloys are the most attractive biomaterials for orthopedic implants and other devices for dental applications due to their relatively good fatigue resistance, excellent biocompatibility, better corrosion resistance in body fluids and lower elasticity modulus compared to the other metallic biomaterials ${ }^{1,3}$. Pure titanium and $(\alpha+\beta)$ Ti-alloys were originally used as structural materials, especially for aerospace structures, and only afterwards they were adopted for biomedical applications. In the recent decades, many titanium alloys have been developed. The Ti6Al4V became the standard alloy and it was the first titanium alloy used as a biomaterial ${ }^{1}$.

Recently, the development of $\beta$ titanium alloys has drawn considerable attention in the biomedical area for their much lower Young's modulus compared to the $\alpha$ $(105 \mathrm{GPa} \text { for pure Ti })^{4}$ or $(\alpha+\beta)$ Ti alloys $(110 \mathrm{GPa}$ for Ti6Al4V) ${ }^{4}$, thus exhibiting a better biomechanical compatibility. A large modulus mismatch between a metallic implant and the adjacent bone (the Young's modulus of the human bone is $10-30 \mathrm{GPa}$ ) will cause the stress-shielding effect, leading to an excessive bone resorption and implant loosening ${ }^{4}$.
Recently developed $\beta$ alloys based on TiNb showing superelasticity $^{5}$ have a high potential to serve as alternatives for the NiTi shape-memory alloys in biomedical applications. The reason for the substitution of $\mathrm{Ni}$ with $\mathrm{Nb}$ is a very good cytocompatibility of $\mathrm{Nb}$ as indicated in the studies in vitro and in vivo ${ }^{6}$. The corrosion resistance of the TiNb alloys has also been shown to be similar or superior to that of Ti alone. Despite the potential benefits of the TiNb alloys, their development for biomedical applications is still at the beginning ${ }^{7}$.

The aim of the presented work is to compare the microstructure effects on the electrochemical behavior of two titanium alloys with different thermal and mechanical treatments. The electrochemical experiments were performed on Ti6Al4V and TiNb with amount fraction $x$ $=22 \% \mathrm{Nb}(\mathrm{Ti} 22 \mathrm{Nb})$ in the $\mathrm{NaCl}$ solution.

Most of the recent works focused on the biocompatible titanium alloys in different stages of the microstructure deal with the mechanical behavior ${ }^{8}$. The effects of the microstructure on the corrosion properties of titanium alloys have not been studied extensively ${ }^{9}$.

\section{EXPERIMENTAL}

The study of electrochemical behavior was performed on two titanium alloys in various states of the thermal and thermomechanical processing. 
The Ti6Al4V alloy with the composition given in Table 1 was studied in three microstructure stages: in the as-received stage and after being rolled above the $\beta$ transus at two diverse temperatures of $900{ }^{\circ} \mathrm{C}$ or 1100 ${ }^{\circ} \mathrm{C}$. The Ti22Nb alloy was tested in following states: in the as-cast state, after being solution annealed at $900{ }^{\circ} \mathrm{C}$ for $1 \mathrm{~h}$ and water quenched or after being solution annealed at $900{ }^{\circ} \mathrm{C}$ for $1 \mathrm{~h}$, aged at $400{ }^{\circ} \mathrm{C}$ for $1 \mathrm{~h}$ and water quenched ${ }^{10}$. The denotation of the specimens in relation to the treatment is listed in Table 2.

Table 1: Chemical composition of the studied Ti6Al4V alloy in mass fractions, $w / \%$

Tabela 1: Kemijska sestava uporabljene zlitine Ti6Al4V v masnih deležih, $w / \%$

\begin{tabular}{|c|c|c|c|c|c|c|c|c|}
\hline $\mathrm{Al}$ & $\mathrm{V}$ & $\mathrm{C}$ & $\mathrm{Fe}$ & $\mathrm{H}$ & $\mathrm{O}$ & $\mathrm{N}$ & $\mathrm{Y}$ & $\mathrm{O}+\mathrm{N}$ \\
\hline $5.50-$ & $3.50-$ & $\max$. & $\max$. & $\max$. & $\max$. & $\max$. & $\max$. & $\max$. \\
6.75 & 4.50 & 0.08 & 0.30 & 0.0125 & 0.20 & 0.05 & 0.005 & 0.25 \\
\hline
\end{tabular}

Table 2: Denotation of experimental specimens

Tabela 2: Oznake vzorcev

\begin{tabular}{|c|c|c|c|}
\hline Stage/alloy & as-recived & $\begin{array}{c}\text { rolled at } \\
900^{\circ} \mathrm{C}\end{array}$ & $\begin{array}{c}\text { rolled at } \\
1100^{\circ} \mathrm{C}\end{array}$ \\
\hline Ti6Al4V & $\mathrm{A}$ & $\mathrm{B}$ & $\mathrm{C}$ \\
\hline Stage/alloy & as-cast & $\begin{array}{c}\text { solution } \\
\text { annealed }\end{array}$ & aged \\
\hline $\mathrm{Ti} 22 \mathrm{Nb}$ & $\mathrm{D}$ & $\mathrm{E}$ & $\mathrm{F}$ \\
\hline
\end{tabular}

For light microscopy the specimen were prepared with the standard metallographic techniques involving grinding, mechanical polishing and etching in Kroll's reagent containing $\mathrm{HF}, \mathrm{HNO}_{3}$ and distilled water $(8: 15$ : $77)$. The microstructures were observed in the etched state using a light microscope GX51.

Electrochemical studies were carried out using linear polarization at room temperature $(22 \pm 1){ }^{\circ} \mathrm{C}$. The corrosion tests were performed using an Autolab PGSTAT $128 \mathrm{n}$ apparatus and a personal computer with software Nova 1.7. The electrochemical measurements were performed using a three-electrode cell containing a working electrode (a specimen) with the exposed area of $\approx 16 \mathrm{~mm}^{2}$ or $\approx 10 \mathrm{~mm}^{2}$, an $\mathrm{Ag} / \mathrm{AgCl}$ (SSC) electrode in saturated $\mathrm{KCl}$ as the reference electrode and a platinum mesh as the counter electrode. A solution of $0.15 \mathrm{M}$ $(0.9 \%) \mathrm{NaCl}$ was used as the electrolyte. The specimens were grinded before the tests with the wheel paper of up to 1000 mesh and then polarized from $-2 \mathrm{~V}$ to $+1.5 \mathrm{~V}$ with a scan rate of $2 \mathrm{mV} / \mathrm{s}$. The scan rate was selected according to ${ }^{11}$.

\section{RESULTS AND DISCUSSION}

The microstructures of the electrochemically tested specimens are shown on the micrographs in Figures 1 and 2. The fine-grained microstructure of the Ti6Al4V alloy presented in Figure 1a consisted of equiaxed $\alpha$ grains (light) in the transformed $\beta$ matrix (dark) containing coarse acicular $\alpha$. After the hot rolling at $900{ }^{\circ} \mathrm{C}$, the coarse $\beta$ grains transformed into fine acicular $\alpha$, as shown in Figure 1b. Figure 1c shows coarse lamellar $\alpha$ at the prior $\beta$-grain boundaries, $\beta$ grains with fine $\alpha$ precipitates in the centre of the specimen and coarse plate-like $\alpha$ at the surface of the specimen after the hot rolling at $1100{ }^{\circ} \mathrm{C}$.

The as-cast dendritic microstructure of the Ti22Nb alloy was formed of $(\alpha+\beta)$ and very fine martensite needles, as presented in Figure 2a. In spite of the annealing at $900{ }^{\circ} \mathrm{C}$ for one hour in argon, the dendritic structure remained conserved and the water quenching from $900{ }^{\circ} \mathrm{C}$ (above the $\beta$ transus) retained the $\beta$ phase
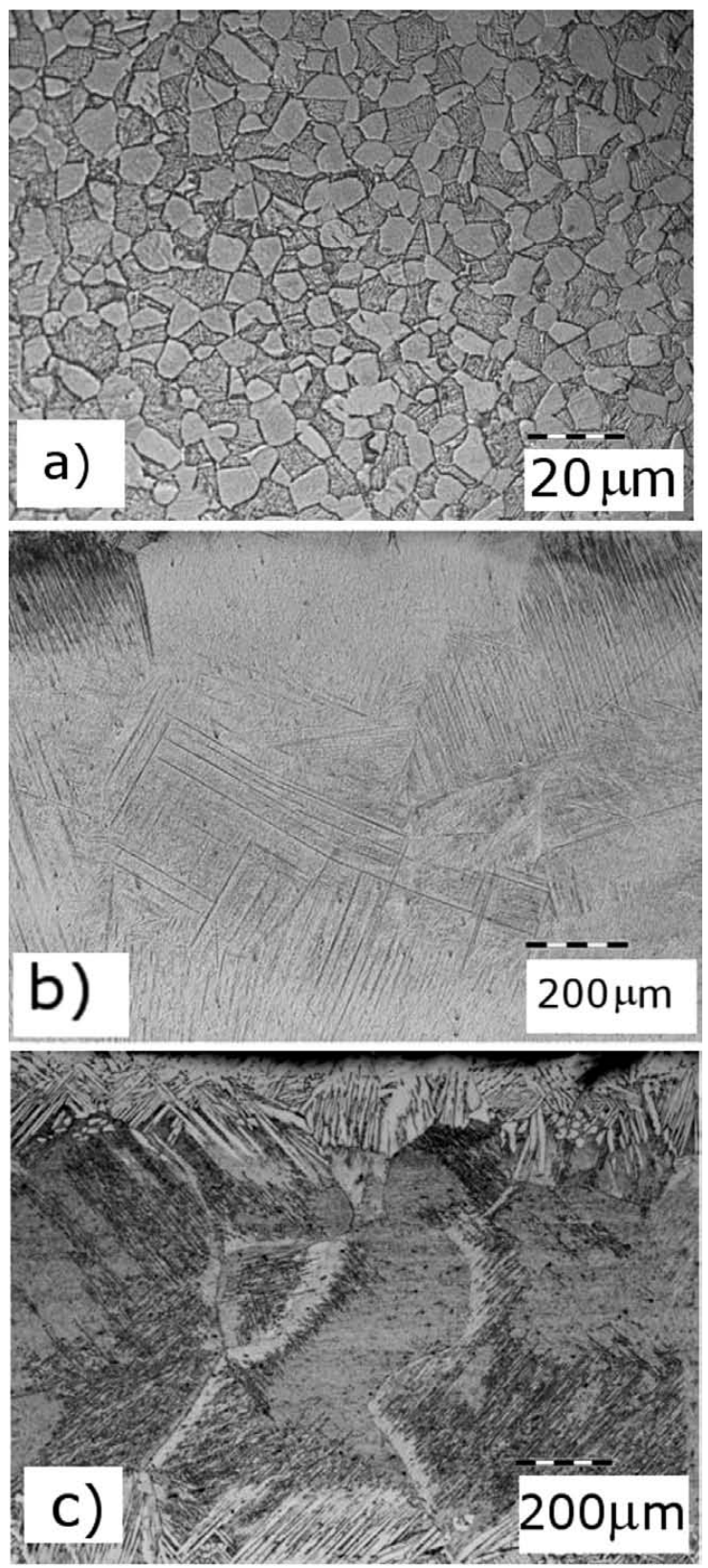

Figure 1: Light micrographs of Ti6Al4V: a) as-received (A), b) after hot rolling at $\left.900{ }^{\circ} \mathrm{C}(\mathrm{B}), \mathrm{c}\right)$ after hot rolling at $1100{ }^{\circ} \mathrm{C}(\mathrm{C})$

Slika 1: Mikrostruktura Ti6Al4V: a) dobavljeno stanje (A), b) po vročem valjanju na $\left.900{ }^{\circ} \mathrm{C}(\mathrm{B}), \mathrm{c}\right)$ po vročem valjanju na $1100{ }^{\circ} \mathrm{C}(\mathrm{C})$ 
Table 3: Values of the corrosion parameters determined with the Tafel plot analysis for Ti6Al4V and Ti22Nb alloys in $0.15 \mathrm{M}$ NaCl solution Tabela 3: Korozijski parametri, določeni s Taflovo analizo za zlitini Ti6Al4V in Ti22Nb v 0,15 M raztopini $\mathrm{NaCl}$

\begin{tabular}{|c|c|c|c|c|c|c|}
\hline $\begin{array}{c}\text { Alloy } \\
\text { State of treatment }\end{array}$ & Ti6Al4V & Ti6Al4V & Ti6Al4V & Ti22Nb & Ti22Nb & Ti22Nb \\
\hline$j_{\text {corr }} /\left(\mu \mathrm{A} / \mathrm{cm}^{2}\right)$ & 7.23 & 4.03 & 6.19 & 14.86 & 20.53 & 20.35 \\
\hline$E_{\text {corr }} / \mathrm{V}$ & -0.467 & -0.444 & -0.361 & -0.330 & -0.536 & -0.545 \\
\hline$R_{\mathrm{p}} / \mathrm{k} \Omega$ & 11.03 & 27.32 & 23.80 & 9.80 & 14.60 & 13.60 \\
\hline
\end{tabular}

that transformed into martensite at lower temperatures ${ }^{10}$. Indeed, very fine martensite needles were observed in the annealed and quenched microstructure at a high
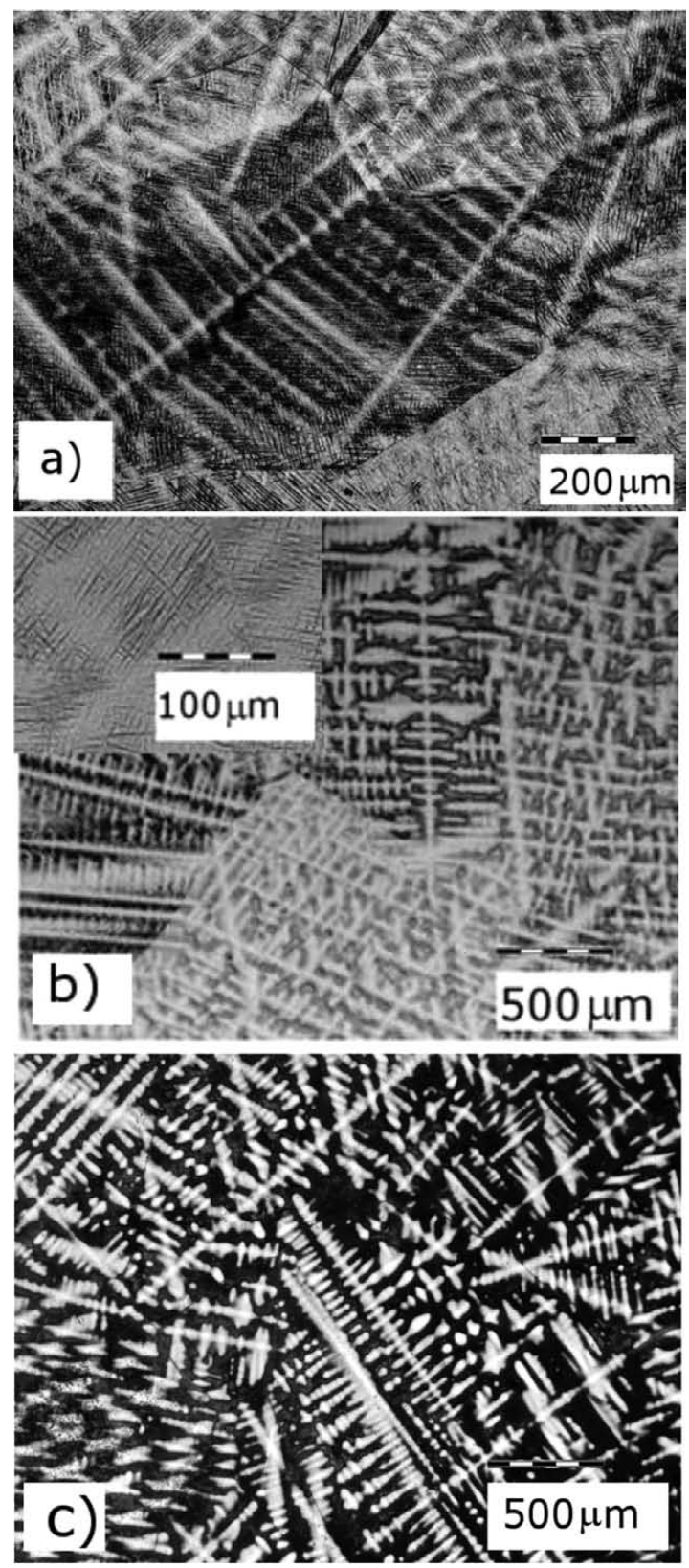

Figure 2: Light micrographs of Ti22Nb: a) as-cast (D), b) after solution annealing $(\mathrm{E}), \mathrm{c})$ after solution annealing and aging $(\mathrm{F})$ Slika 2: Mikrostruktura Ti22Nb: a) lito stanje (D), b) po raztopnem žarjenju (E), c) po raztopnem žarjenju in staranju $(\mathrm{F})$ magnification of light microscopy, as shown in Figure 2b. After the aging at $400{ }^{\circ} \mathrm{C}$ and water quenching the dendritic microstructure was formed of the $(\alpha+\beta)$ phases (Figure 2c). No martensite was observed.

The linear-polarization results for the Ti6Al4V and Ti22 $\mathrm{Nb}$ alloys in the $0.15 \mathrm{M} \mathrm{NaCl}$ solution are shown in Figures 3 and 4. The polarization parameters, including the corrosion potential $\left(E_{\text {corr }}\right)$, the corrosion current density $\left(j_{\text {corr }}\right)$ and the polarization resistence $\left(R_{\mathrm{p}}\right)$ obtained using the Tafel extrapolation method, are listed in Table 3.

Comparing the linear polarization curves of the three specimens of the Ti6Al4V alloy shown in Figure 3, it can be seen that there are no significant diferences between the cathodic polarization curves. The nature of the anodic polarization curve for specimen C (Figure 3, curve $C$ ) indicates an almost stable passive behavior over the entire potential range. The corrosion potential $\left(E_{\text {corr }}\right)$ estimated from the Tafel region is $-0.361 \mathrm{~V}$ (SSC). The passive current first continuously increases with the potential, but at around $0 \mathrm{~V}$ a slight decrease is observed; then, from about $0.5 \mathrm{~V}$ the passive current slightly increases with the higher potentials. The $E_{\text {corr }}$ of samples

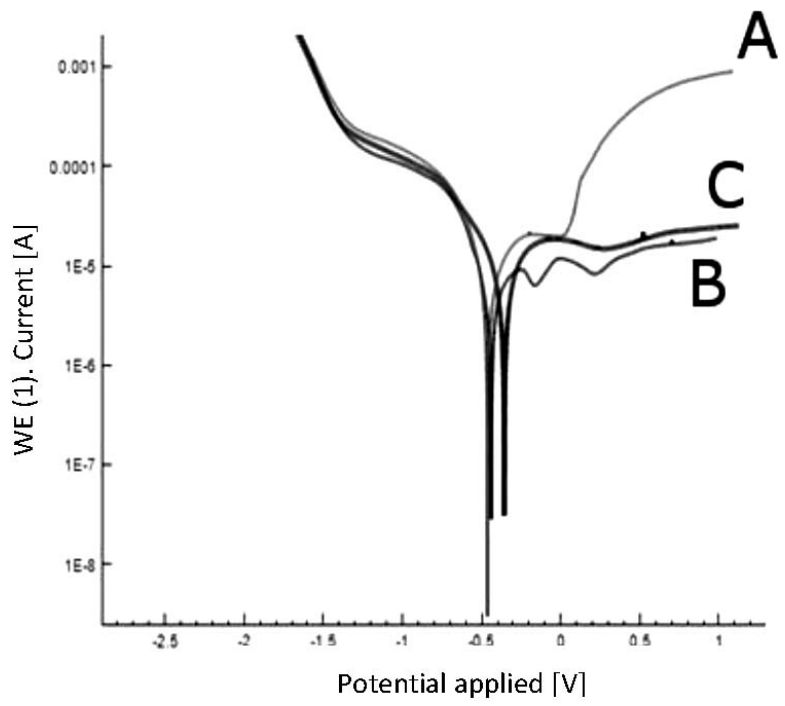

Figure 3: Linear polarization curves obtained in the $0.15 \mathrm{M} \mathrm{NaCl}$ solution at room temperature for different Ti6Al4V stages: A as-received, B - after hot rolling at $900{ }^{\circ} \mathrm{C}, \mathrm{C}$ - after hot rolling at $1100{ }^{\circ} \mathrm{C}$

Slika 3: Linearne polarizacijske krivulje, dobljene v 0,15 M raztopini $\mathrm{NaCl}$ pri sobni temperaturi za Ti6Al4V, za stanja: A - dobavljeno stanje, B - po vročem valjanju na $900{ }^{\circ} \mathrm{C}, \mathrm{C}$ - po vročem valjanju na $1100{ }^{\circ} \mathrm{C}$ 


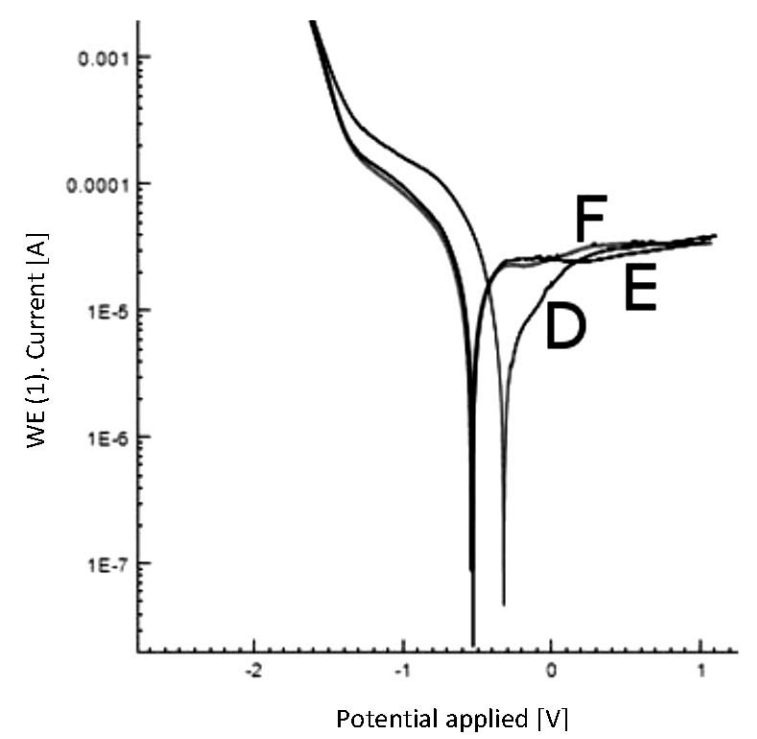

Figure 4: Linear polarization curves obtained in the $0.15 \mathrm{M} \mathrm{NaCl}$ solution at room temperature for different Ti22 $\mathrm{Nb}$ stages: $\mathrm{D}$ - as-cast, $\mathrm{E}$ - after solution annealing at $900{ }^{\circ} \mathrm{C}, \mathrm{F}$ - after aging at $400{ }^{\circ} \mathrm{C}$

Slika 4: Linearne polarizacijske krivulje, dobljene v $0,15 \mathrm{M}$ raztopini $\mathrm{NaCl}$ pri sobni temperaturi za Ti22Nb, za stanja: D - lito stanje, E po raztopnem žarjenju na $900{ }^{\circ} \mathrm{C}, \mathrm{F}$ - po staranju na $400{ }^{\circ} \mathrm{C}$

A and B (curves A, B, Figure 3) shifts to more negative values than in the case of specimen $C$. For specimen $A$, the passive film is broken down at more positive potentials than for sample B and then the current sharply increases (Figure 3, curve A). Specimen B (Figure 3, curve B) shows several active-passive transitions followed by the passivation domain at the higher potentials. This behavior may be related to the effect of the presence of the fine acicular $\alpha$ phase in the microstructure that can act as effective galvanic couples leading to a higher rate of corrosion ${ }^{12}$. Indeed, the microstructural features of all three states influenced not only the passivation but also the rate of corrosion that was $(0.12,0.07$ and 0.10$) \mathrm{mm}$ per year for the equiaxed $(\alpha+$ $\beta$ ) (A), acicular $\alpha$ in the transformed $\beta$ grains (B) and coarse lamellar $(\alpha+\beta)(\mathrm{C})$, respectively.

The samples of the Ti22Nb alloy showed quite similar polarization behaviors with the increasing potential. The as-cast specimen of Ti22Nb (Figure 4, curve D) exhibited a corrosion potential $E_{\text {corr }}$ of $-0.324 \mathrm{~V}$ (SSC), which was slightly more noble than the corrosion potentials observed for samples E $(-0.499 \mathrm{~V}(\mathrm{SSC}))$ and $\mathrm{F}$ $(-0.537 \mathrm{~V}(\mathrm{SSC}))$. The polarization behavior can be regarded as stable passivity. Comparing the microstructural features of the three specimens, it can be concluded that the more $\beta$ is retained, the higher stability of the passivation region can be expected. Sample D having a dendritic microstructure with very fine martensite had the lowest corrosion rate $(0.26 \mathrm{~mm}$ per year), unlike specimens $\mathrm{E}$ and $\mathrm{F}$ after the heat treatment $(0.34 \mathrm{~mm}$ and $0.33 \mathrm{~mm}$ per year, respectively).

The electrochemical behaviors of both alloys in the $0.15 \mathrm{M} \mathrm{NaCl}$ solution are dissimilar, as seen in Figures 3 and 4. For the Ti6Al4V alloy, a passive region followed by a breakdown and repassivation was observed on the anodic polarization diagrams in all three cases. On the contrary, the Ti22Nb alloy showed a relatively stable passivation region over the entire potential range. However, the corrosion rate for Ti22Nb was about three times higher. No visible surface changes were observed on any specimens after the anodic polarization.

\section{CONCLUSION}

Based on the experimental results it can be concluded that the corrosion resistance of titanium alloys is determined not only by the alloy composition but also by the microstructure formed after different thermal or thermomechanical treatments.

The electrochemical behavior of the Ti6Al4V and Ti22Nb alloys was studied in the $0.15 \mathrm{M}(0.9 \%)$ physiological $\mathrm{NaCl}$ solution at room temperature. The experimental samples of the Ti6Al4V alloy were tested in different states of the thermomechanical treatment: the as-received state with the $(\alpha+\beta)$ microstructure and after being hot rolled at $900{ }^{\circ} \mathrm{C}$ and $1100{ }^{\circ} \mathrm{C}$ with a fine acicular $\alpha$ phase and a coarse lamellar $(\alpha+\beta)$ phase, respectively. The samples of $\mathrm{Ti} 22 \mathrm{Nb}$ were studied in the following stages: the as-cast stage with very fine martensite needles in the dendritic $(\alpha+\beta)$ microstructure, the stage after being heat treated at $900{ }^{\circ} \mathrm{C}$ or quenched, having martensite needles in the retained $\beta$ phase and after being aged at $400{ }^{\circ} \mathrm{C}$, having a dendritic $(\alpha+\beta)$ microstructure. With respect to the corrosion related to the microstructural features, Ti6Al4V in all three investigated stages displayed lower values of the corrosion rate than measured for the Ti22 $\mathrm{Nb}$ alloys.

Nevertheless, the samples of the Ti22Nb alloys showed a more stable passivation behavior than the Ti6Al4V alloy. No visible surface changes were observed on any specimens after the anodic polarization.

\section{Acknowledgments}

The experimental work was performed with the support of projects No. TA03010804 financed by the Technology Agency of the Czech Republic, No. CZ.1.05/2.1.00/01.0040 "Regional Materials Science and Technology Centre" within the frame of the operational program "Research and Development for Innovations" financed by the Structural Funds and from the state budget of the Czech Republic, and the Grant of SGS, No. SP2013/64 - "Specific research in metallurgy, material and processing engineering" financed by VŠB Technical University of Ostrava, Czech Republic.

\section{REFERENCES}

${ }^{1}$ T. C. Niemeyer, C. R. Grandini, L. M. C. Pinto, A. C. D. Angelo, S. G. Schneider, Journal of Alloys and Compounds, 476 (2009) 1-2, 172-175, doi:10.1016/j.jallcom.2008.09.026 
${ }^{2}$ H. Zohdi, H. R. Shahverdi, S. M. M. Hadavi, Electrochemistry Communications, 13 (2011) 8, 840-843, doi:10.1016/j.elecom.2011. 05.017

${ }^{3}$ Y. J. Bai, Y. B. Wang, Y. Cheng, F. Deng, Y. F. Zheng, S. C. Wei, Materials Science and Engineering C, 31 (2011) 3, 702-711, doi:10.1016/j.msec.2010.12.010

${ }^{4}$ F. X. Xie, X. B. He, S. L. Cao, X. Lu, X. H. Qu, Corrosion Science, 67 (2013), 217-224, doi:10.1016/j.corsci.2012.10.036

${ }^{5}$ H. Y. Kim, Y. Ikehara, J. I. Kim, H. Hosoda, S. Miyazaki, Acta Materialia, 54 (2006) 9, 2419-2429, doi:10.1016/j.actamat.2006. 01.019

${ }^{6}$ H. Matsuno, A. Yokoyama, F. Watari, M. Uo, T. Kawasaki, Biomaterials, 22 (2001) 11, 1253-1262, doi:10.1016/S0142-9612(00) 00275-1
${ }^{7}$ R. E. McMahon, J. Ma, S. V. Verkhoturov, D. Munoz-Pinto, I. Karaman, F. Rubitschek, H. J. Maier, M. S. Hahn, Acta Biomaterialia, 8 (2012) 7, 2863-2870, doi:10.1016/j.actbio.2012.03.034

${ }^{8}$ M. Niinomi, M. Nakai, J. Hieda, Acta Biomaterialia, 8 (2012) 11, 3888-3903, doi:10.1016/j.actbio.2012.06.037

${ }^{9}$ M. Atapour, A. Pilchak, G. S. Frankel, J. C. Williams, M. H. Fathi, M. Shamanian, Corrosion, 66 (2010) 6, 065004-1-065004-9, doi:10. 5006/1.3452400

${ }^{10}$ P. Štěpán, M. Losertová, Proc. of the 21st International Conference on Metallurgy and Materials, Metal 2012, Brno, 2012, 1581

${ }^{11}$ S. Barril, S. Mischler, D. Landolt, Wear, 259 (2005) 1-6, 282-291, doi:10.1016/j.wear.2004.12.012

${ }^{12}$ F. Karimzadeh, M. Heidarbeigy, A. Saatchi, Journal of Materials Processing Technology, 206 (2008) 1-3, 388-394, doi:10.1016/ j.jmatprotec.2007.12.065 